\title{
GPC3 Positive
}

National Cancer Institute

\section{Source}

National Cancer Institute. GPC3 Positive. NCI Thesaurus. Code C134492.

An indication that GPC3 expression has been detected in a sample. 